\title{
METODO OPTIMIZADO PARA LA EXTRACCIÓN DE DNA DE Sargassum liebmannii
}

\author{
Optimized method for the extraction of DNA from Sargassum liebmannii
}

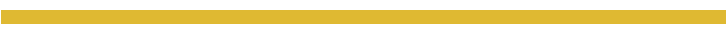

Hwan Woo Jung Kim

Departamento de Producción Agrícola. Centro Universitario de Ciencias Biológicas y Agropecuarias Universidad de Guadalajara. Camino Ramón Padilla Sánchez 2100 Nextipac, Zapopan, Jal. México. Ana Paulina Velasco-Ramírez

Departamento de Producción Agrícola. Centro Universitario de Ciencias Biológicas y Agropecuarias. Universidad de Guadalajara. Camino Ramón Padilla Sánchez 2100 Nextipac, Zapopan, Jal. México.

*Autor para correspondencia: pauvela73@hotmail.com Rosalba Mireya Hernández-Herrera

Departamento de de Botánica y Zoología. Centro Universitario de Ciencias Biológicas y Agropecuarias. Universidad de Guadalajara. Camino Ramón Padilla Sánchez 2100 Nextipac, Zapopan, Jal. México. Ildefonso Enciso-Padilla

Departamento de Ecología. Centro Universitario de Ciencias Biológicas y Agropecuarias. Universidad de Guadalajara. Camino Ramón Padilla Sánchez 2100 Nextipac, Zapopan, Jal. México. Martha Escoto Delgadillo

Departamento de Producción Agrícola. Centro Universitario de Ciencias Biológicas y Agropecuarias Universidad de Guadalajara. Camino Ramón Padilla Sánchez 2100 Nextipac, Zapopan, Jal. México.
\end{abstract}

\begin{abstract}
Resumen
Las altas concentraciones de polisacáridos, polifenoles y metabolitos secundarios, contenidos en las macroalgas, son factores que impiden el aislamiento del ácido desoxirribonucleico (DNA) y por ende inhibe la reacción en cadena de la polimerasa (PCR) que es el inicio para la aplicación de cualquier marcador molecular. En el presente estudio, se documentó la aplicación de seis métodos de extracción; cuatro de ellos convencionales y dos kits comerciales. La mayor eficiencia en la extracción de DNA se obtuvo con un método convencional con modificaciones. Dichas modificaciones consistieron en sumergir el tejido algal en B-mercantoethanol y la adición de la sal DIECA en el buffer de extracción. Para probar la pureza del DNA, adicionalmente a los métodos de electroforésis y espectrofotometría, se realizó una PCR para el marcador molecular ISSR, obteniendo fragmentos amplificados al utilizar la modificación mencionada.
\end{abstract}

Palabras clave: Extracción de DNA, macroalgas, ISSR.

\begin{abstract}
Macroalgae contains high concentrations of polysaccharides, polyphenols and secondary metabolites. Those compounds are factors that prevent the isolation of deoxyribonucleic acid (DNA) and therefore inhibit the polymerase chain reaction (PCR) that is the beginning for the application of any molecular marker. In the present study, the application of six extraction methods was documented; four of them conventional and two commercial kits. The highest efficiency in DNA extraction was obtained with a conventional method with modifications. Said modifications consisted of immersing the algal tissue in $B$ mercantoethanol and the addition of the DIECA salt in the extraction buffer. To test the purity of the DNA, in addition to the electrophoresis and spectrophotometry methods, a PCR was performed for the ISSR molecular marker, obtaining amplified fragments using the aforementioned modification.
\end{abstract}

Keywords: DNA extraction, macroalgae, ISSR 


\section{Introducción}

Con el desarrollo de la Reacción en Cadena de la Polimerasa (PCR), surgieron los llamados marcadores moleculares que se convirtieron en una herramienta imprescindible en estudio de genética de poblaciones y en la caracterización de poblaciones. La utilización de esta herramienta inicia con la obtención de la molécula objetivo, el DNA. De la concentración de esta molécula y la pureza de la misma, depende el éxito en la obtención de datos confiables. Las técnicas de marcadores moleculares basadas en PCR han sido ampliamente utilizadas para la determinación de estudios específicos entre varias especies del género Sargassum, así como para calcular la diversidad genética en diferentes especies (Engelen et al., 2005; Zhao et al., 2007; Byeon et al., 2019). Este tipo de estudios, requiere obtener una buena calidad de DNA genómico (Aljanabi y Martinez,1997). La dificultad del aislamiento de DNA de macroalgas pardas esta atribuida a la complicada estructura de la pared celular y la alta concentración de niveles de polifenoles y polisacáridos, tales como ácido algínico y fucoidan, que se han reportado como compuestos emulsificantes, antioxidantes, antitumorales e inmunoestimulantes (Hahn et al., 2012). Estos compuestos impiden la amplificación de los cebadores o iniciadores en la reacción de PCR, inhiben la actividad de la enzima Taq polimerasa y limitan la actividad de las enzimas de restricción (Porebski et al., 1997). Por consiguiente, la amplificación exitosa de una región especifica génica por PCR depende en gran medida de la cantidad y calidad de los ácidos nucleicos extraídos de los especímenes algales. Los marcadores moleculares ISSR (Inter Simple Sequence Repeat) se caracterizan como marcadores dominantes sin aptitud discriminante entre heterocigotos $\mathrm{u}$ homocigoto $\mathrm{y}$ los productos están basado en secuencias de microsatélites, que son repeticiones de dinucleótidos (GT) o (CA), distribuidas a lo largo del sitio genómico de un organismo. No obstante, el análisis permite de múltiples loci (entre 25 a 50 bandas) en la misma reacción. Comúnmente, los cebadores se fijan en el extremo 5 'o 3 ' mediante 1 o 4 bases degeneradas, amplificando la molécula de DNA utilizando la técnica de PCR (Zietkiewicz et al., 1994; Bornet y Branchard, 2001; González y Aguirre, 2007). En el presente estudio, se probaron seis métodos de extracción de DNA en muestras de Sargassum liebmannii y se utilizó la técnica PCR para el marcador ISSR (Inter Simple Sequence Repeat), para comprobar la calidad del DNA y la amplificación de las muestras.

\section{Materiales y métodos}

Colecta de Sargassum liebmannii

El trabajo se realizó a finales del mes de julio del 2020. Se realizaron recorridos en distintas localidades a lo largo de la costa de Jalisco tomando muestras de algas de las zonas submareal e intermareal, colectando todos los crecimientos visibles del género Sargassum.

Los especímenes fueron colectados del sustrato con ayuda de una espátula y colocadas en bolsas de plástico, preserván- dose en agua de mar fría dentro de una hielera.

Todas las muestras fueron debidamente etiquetadas y transportadas para su posterior identificación y análisis, en el Laboratorio de Marcadores Moleculares del Departamento de Producción Agrícola, del Centro Universitario de Ciencias Biológicas y Agropecuarias (CUCBA) perteneciente a la Universidad de Guadalajara.

Preservación de las muestras de Sargassum liebmannii Una vez en el laboratorio, los fragmentos colectados se lavaron dos veces con agua deestilada para remover conchas y arena, se eliminó el exceso de agua. Se almacenaron a una temperatura de $-20^{\circ} \mathrm{C}$ hasta el momento de procesamiento.

\section{Protocolos de extracción de DNA genómico}

Se evaluaron seis protocolos de extracción de DNA en este estudio. El DNA se aisló por triplicado con cada protocolo. Los primeros pasos experimentales fueron siempre los mismos. Se obtuvo un volumen total de $10 \mathrm{~mL}$ de cultivo líquido de las algas centrifugado (10 min, $5000 \mathrm{rpm}, \mathrm{RT})$, el sedimento obtenido se suspendió en $1 \mathrm{ml}$ de Tris-EDTA (TE; $10 \mathrm{mM}$ Tris$\mathrm{HCl} \mathrm{pH} 7,6$, EDTA $0,1 \mathrm{mM}$ ). Esto se repitió dos veces para asegurar la eliminación completa de carbohidratos y proteínas. Al final, el sedimento celular lavado se suspendió en un buffer, dependiendo de la especificación de cada protocolo elegido.

\section{Extracción con molienda de Nitrógeno líquido (NL)}

El primer método de extracción se realizó como se describe Porebski, 1997. Brevemente, las células de algas, suspendidas en buffer TE, se molieron hasta obtener un polvo fino, utilizando un mortero y pistilo preenfriado. La muestra se resuspendió en $600 \mu \mathrm{L}$ de búfer de extracción de bromuro de cetiltrimetilamonio (CTAB) (CTAB al 1\% (Sigma, Saint Louis, EE. UU.), $\mathrm{NaCl}$ 1,4 M, Tris pH $100 \mathrm{Mm} \mathrm{8.0,} \mathrm{EDTA} 20 \mathrm{mM}$ ), se transfirió a un tubo de microcentrífuga de $2 \mathrm{ml}$ y se incubó en hielo durante $1 \mathrm{~h}$. El DNA fue más extraído con fenolcloroformo-alcohol isoamílico (Phe / Chl / IAA, 25: 24: 1) (Sigma, Saint Louis, EE.UU.) seguido de precipitación de DNA con isopropanol. Obtenido el sedimento se resuspendió en 100 $\mu \mathrm{L}$ de buffer TE con ARNasa A $(50 \mu \mathrm{g} / \mathrm{mL}$, Sigma, Saint Louis, EE. UU.), Y después de la centrifugación (5 min, 13.000 rpm, RT), los restos celulares se eliminó, mientras que el sobrenadante transparente se transfirió a un tubo nuevo.

\section{Extracción con molienda en $C T A B$}

El segundo método de extracción fue el descrito por Doyle y Doyle, (1990). El sedimento de algas se molió en precalentamiento $\left(60^{\circ} \mathrm{C}\right)$. Se elaboró el buffer de extracción CTAB (2\% CTAB (Sigma, Saint Louis, USA), NaCl 1,4 M, Tris $100 \mathrm{mM}$ pH 8,0, EDTA $20 \mathrm{mM}$ ).

Luego, la mezcla se transfirió a un tubo de microcentrífuga de $2 \mathrm{~mL}$ y se incubó a $60{ }^{\circ} \mathrm{C}$ durante $1 \mathrm{~h}$. El DNA fue extraído una vez con cloroformo-alcohol isoamílico (Chl /IAA, 24: 1) (Sigma, Saint Louis, EE. UU.) Y precipitó con dos volúmenes de isopropanol. El pellet obtenido se lavó con EtOH al 70\%, se secó y se disolvió en $100 \mu \mathrm{L}$ de buffer TE con ARNasa A 
(50 $\mu \mathrm{g} / \mathrm{mL}$, Sigma, Saint Louis, EE.UU).

\section{Extracción con Proteinasa $K$}

El tercer método de extracción fue el descrito por Alianabi y Martínez, (1997). El sedimento de algas se molió junto con el buffer de extracción ( $\mathrm{NaCl}$, Tris-Hcl, EDTA, SDS y Proteinasa K. Luego la mezcla se transfirió a un tubo de microcentrífuga de $2 \mathrm{~mL}$ y se incubó a $60{ }^{\circ} \mathrm{C}$ durante $24 \mathrm{~h}$, seguido de precipitación con isopropanol a $-20{ }^{\circ} \mathrm{C}$ e incubado a la misma temperatura durante $24 \mathrm{~h}$. El pellet obtenido se lavó con EtOH al 70\%, se secó y se disolvió en $50 \mu \mathrm{L}$ de buffer TE.

Extracción con Kits comerciales DNeasyß Plan Mini Kit (Quiagen) y Wizard® Genomic DNA purification Kit (Promega)

Dos kits disponibles en el mercado, diseñados para Purificación de DNA genómico, basado en buffers específicos, formulaciones y columnas de membranas de sílice que se unen al DNA (DNeasy® Plan Mini Kit (Quiagen)) Kit de purificación de DNA genómico de plantas y el kit de purificación de DNA de plantas, bacterias y levaduras Wizard ${ }^{\circledR}$ Genomic DNA purification Kit (Promega). Todos los pasos se realizaron estrictamente de acuerdo con instrucciones proporcionadas por el fabricante.

\section{Extracción con molienda en CTAB con modificación}

El sexto método de extracción fue el descrito por Phillips (2001). Dicho método describe una modificación del método CTAB. El tejido del alga previamente triturado con Nitrógeno líquido fue sumergido durante $4 \mathrm{~h}$ en B-mercantoethanol y posteriormente diez lavados con agua $\mathrm{dH} 2 \mathrm{O}$. Se añadió un buffer de extracción CTAB, Tris, EDTA, NaCl, PVP, DIECA. Enseguida se incubó a $50{ }^{\circ} \mathrm{C}$ durante $30 \mathrm{~min}$. Para la precipitación del DNA se añadió EtOH absoluto a $-20{ }^{\circ} \mathrm{C}$ durante $24 \mathrm{~h}$, después se realizaron dos lavados con EtOH al $70 \%$ a $-20{ }^{\circ} \mathrm{C}$, el pellet se secó y se disolvió en $50 \mu \mathrm{L}$ de buffer TE.

\section{Concentración y pureza del DNA}

Para cada procedimiento de extracción, se verificó la calidad y la concentración de DNA obtenido, utilizando los métodos de electroforesis en gel de agarosa al $1 \%$ y espectrofotometría Quawell ${ }^{\circledR}$ con lecturas de absorbancia a 230, 260 y $280 \mathrm{~nm}$; donde la lectura de $230 \mathrm{~nm}$ mide contaminantes, como sales caotrópicas, fenoles o carbohidratos, mientras que la relación entre las lecturas 260 y $280 \mathrm{~nm}$ estiman la calidad de DNA.

\section{Prueba con ISSR}

El DNA extraído por los seis diferentes métodos, se amplificó en un volumen de reacción de $20 \mu \mathrm{L}$, la cual contenía regulador PCR 1X, MgCl2 $2.5 \mathrm{mM}, 0.8 \mu \mathrm{M}$ de cada cebador, dNTPs $0.25 \mathrm{mM}, 4 \mathrm{ng}$ de muestra de DNA Y 0.05 U de Taq Polimerasa Promega ${ }^{\circledR}$

La amplificación del DNA se realizó utilizando los termocicladores de la marca TECHNE y APOLLO con capa- cidad para 96 muestras cada uno. El estudio se realizó utilizando tres secuencias del cebador (16: YRG ACA GAC AGA CA, 812: GAGAGGAGAGAGAGAA y 902: GTCTGTGTGTGTAY). El programa utilizado para la reacción en cadena de la polimerasa, consistió en un ciclo de desnaturalización de 3 min a $95^{\circ} \mathrm{C}$, seguido de 40 ciclos de $45 \mathrm{~s}$ a $95{ }^{\circ} \mathrm{C}$ (desnaturalización del DNA), 45 s a $52{ }^{\circ} \mathrm{C}$ (alineamiento del cebador al DNA) y 1 min $30 \mathrm{~s}$ a $72{ }^{\circ} \mathrm{C}$ (extensión de fragmento de DNA), luego un periodo de extensión de $10 \mathrm{~min}$ a $72{ }^{\circ} \mathrm{C}$. Finalmente, las muestras se mantuvieron a una temperatura de $4{ }^{\circ} \mathrm{C}$. Los productos de amplificación fueron separados en geles de agarosa al 2.0\% y visualizados con luz ultravioleta utilizando tinción con bromuro de etidio.

\section{Análisis de datos}

Se determinaron las medias y las desviaciones estándares de los valores de absorbancia y concentración de DNA, para cada uno de los métodos de extracción analizados. Los resultados fueron procesados con ayuda del paquete estadístico para Windows (Statgraphics ${ }^{\circledR}$ Centurion XV (New Jersey, United States)). Se realizó un análisis de varianza (ANOVA) para comparar las medias entre los parámetros analizados. Se consideraron significativos los valores $\mathrm{P}>0.01$.

\section{Resultados y discusión}

Los resultados de los valores de absorbancia de los métodos utilizados se muestran en el Cuadro 1. Con los métodos de extracción de DNA con molienda de Nitrógeno líquido y el método con molienda en CTAB se obtuvo poco DNA de color pardo y gelatinoso y de calidad muy baja $(1.43 \pm 0.03,1.50 \pm$ 0.02 respectivamente), lo cual lo demuestra el gel de calidad de agarosa al 1\%, donde no hubo evidencia de bandas, solo presencia de contaminantes (carbohidratos y/o proteínas) (Figura 1. a y b). Con el método de extracción con Proteinasa K, el kit comercial de Quiagen y el Kit comercial de Promega, se obtuvo poco DNA, degradado y baja calidad como lo demuestran la relación de lecturas de absorbancia 260:280 (1.47 $\pm 0.23,1.32 \pm 0.50$ y $1.24 \pm 0.02$ respectivamente) y la Figura 1. c, d y e.

En el caso de extracción de DNA del kit comercial de Quiagen que utiliza columnas de centrifugación basadas en membranas de sílice, las bajas proporciones de A260: 280 pueden deberse a una fuerte contaminación de proteínas. Considerando que, las bajas relaciones A260: 230 puede indicar un exceso de fenol residual o de carbohidratos, un problema que se encuentra comúnmente en el DNA aislamiento de plantas y algas.

El método de extracción con molienda en CTAB con modificaciones se obtuvieron bandas de DNA mejor definidas (Figura 1. f) y resultó de mejor calidad como lo demuestra las lecturas de absorbancia 260:280 (1.77 \pm 0.03$)$. 
Cuadro 1. Comparación de los seis diferentes métodos de extracción de DNA para Sargassum liebmannii

\begin{tabular}{|c|c|c|c|}
\hline \multirow[t]{2}{*}{ Método de extracción } & \multicolumn{2}{|c|}{ Absorbancia } & \multirow{2}{*}{$\begin{array}{c}\text { Concentración de DNA } \\
(\mathrm{ng} / \mu \mathrm{L})\end{array}$} \\
\hline & $260: 280$ & 260:230 & \\
\hline $\begin{array}{l}\text { Extracción con molienda de } \\
\text { Nitrógeno líquido (NL) }\end{array}$ & $1.43 \pm 0.03$ & $1.15 \pm 0.12$ & $50.90 \pm 0.15$ \\
\hline $\begin{array}{l}\text { Extracción con molienda en } \\
\text { CTAB }\end{array}$ & $1.50 \pm 0.02$ & $1.24 \pm 0.03$ & $12.07 \pm 0.7$ \\
\hline Extracción con Proteinasa K & $1.47 \pm 0.23$ & $0.34 \pm 0.06$ & $51.21 \pm 618.80$ \\
\hline $\begin{array}{l}\text { Kit comercial DNeasy }{ }^{\circledR} \\
\text { Plan Mini Kit (Quiagen) }\end{array}$ & $1.32 \pm 0.50$ & $0.41 \pm 0.08$ & $27.56 \pm 2.15$ \\
\hline $\begin{array}{l}\text { Kit comercial Wizard } ® \\
\text { Genomic DNA purification } \\
\text { Kit (Promega) }\end{array}$ & $1.24 \pm 0.02$ & $0.51 \pm 0.07$ & $34.085 \pm 4.79$ \\
\hline $\begin{array}{l}\text { Extracción con molienda en } \\
\text { CTAB con modificación }\end{array}$ & $1.77 \pm 0.03$ & $1.63 \pm 0.06$ & $76.69 \pm 21.96$ \\
\hline
\end{tabular}

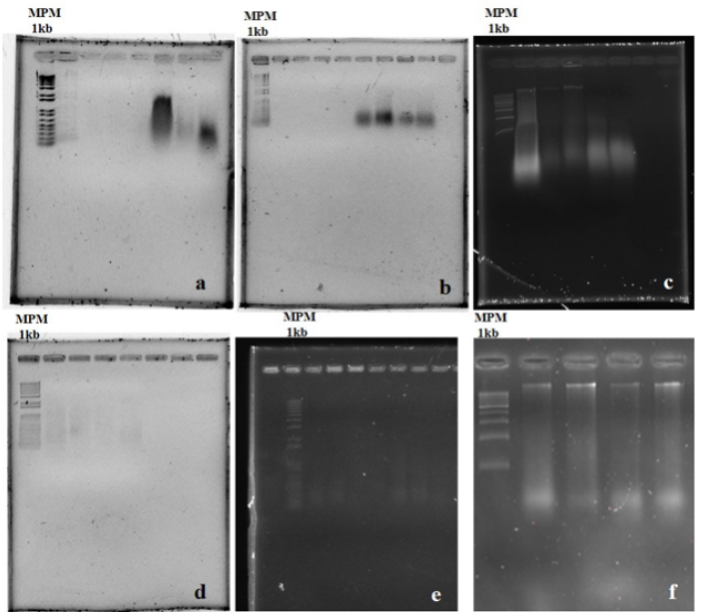

Figura 1. Resultados de calidad de ADN de los métodos de extracción probados por medio de electroforesis en geles de agarosa al 1\%. a) Extracción con molienda en Nitrógeno Líquido. b) Extracción con molienda en CTAB. c) Extracción con Proteinasa K. d) Kit comercial Quiagen. e) Kit comercial Promega y f) Extracción con molienda en CTAB con modificación.

Todos los métodos de extracción de DNA fueron aplicados en la técnica de PCR, sin embargo, en los primeros cinco (Extracción con molienda de Nitrógeno líquido (NL), extracción con molienda en CTAB, extracción con Proteinasa K, kit comercial DNeasy ${ }^{\circledR}$ Plan Mini Kit (Quiagen) y el kit comercial Wizard® Genomic DNA purification Kit (Promega)) se utilizó DNA sin diluir debido a la baja concentración y no hubo éxito de fragmentos amplificados.

La aplicación de la técnica PCR con el DNA extraído por el método de molienda en CTAB con modificación, resultó exitosa ya que se logró obtener fragmentos de amplificación con los tres cebadores inter microsatélites (ISSR) probados (Figura 2).

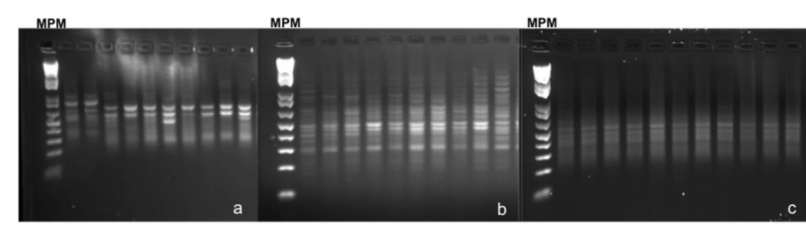

Figura 2. Patrones de amplificación generados con el marcador molecular ISSR en Sargassum liebmannii. MPM (Marcador de Peso Molecular $1 \mathrm{~kb}$ ), a) cebador 16, b) 812 y c) cebador 902 .

El primer paso para llegar a la aplicación de cualquier marcador molecular, es la obtención de DNA de buena calidad, sin embargo, no siempre se puede obtener de manera sencilla. Las macroalgas tienen una estructura celular complicada compuesta de varios polisacáridos tales como celulosa, fúcanos, sulfatados, laminarias y alginatos (Mabeau et al., 1990; Michel et al., 2010), que dificultan el proceso de extracción de DNA. La morfología que las constituye, también es un factor importante a considerar durante la extracción de DNA, porque la homogeneización de los tejidos de algas es una tarea difícil; por lo tanto, un método eficiente de homogeneización diferente es esencial para una extracción de DNA en algas pardas (Gautham et al., 2017). El éxito del método de extracción de DNA desarrollado por Phillips (2001) para varias especies de Sargassum se atribuyó al uso de un buffer de lisis altamente reductivo, preparado con mayores cantidades, que las acostumbradas por otros protocolos y el uso previo de B-ME como agente reductor, así como la adición de dietilditiocarbámico (DIECA) que es un componente poco común para la extracción de DNA, sin embargo forma parte de la estandarización del protocolo de extracción sugerido por Phillips (2001). El método de extracción implementado en este proyecto para $S$. liebmannii resultó simple, rápido y barato para los individuos colectados de Sargassum; Mendoza (2003) utilizó este mismo método para obtener DNA de S. lapazeanum obteniendo resultados exitosos.

\section{Conclusiones}

El presente estudio muestra un método optimizado, que incorpora algunas soluciones clave de ensayos previamente descritos de aislamientos de DNA en macroalgas, implica una lisis celular, precipitación y lavado de DNA que garantiza la mejora de la calidad y concentración de DNA, para ser aplicado en la técnica de PCR con marcadores moleculares dominantes como los ISSR, ya que este tipo de marcadores no exige un grado de pureza como los marcadores de origen codominante.

\section{Literatura citada}

- Aljanabi, S.M., I. Martínez (1997). Universal and rapid salt-extraction of high quality genomic DNA for PCRbased techniques. Nucleic Acids Research, 25(22), 46924693.

- Bornet, B., Branchard, M. (2001). Nonanchored Inter Simple Sequence Repeat (ISSR) markers: Reproducible and specific tools for genome fingerprinting. Plant Molecular Biology Reporter, 19(3), 209-215.

- Byeon, S.Y., Oh, H.-J., Kim, S., Yun, S. H., Kang, J. H., 
Park,S. R., Lee, H. J. (2019). The origin and population genetic structure of the 'golden tide' seaweeds, Sargassum horneri, in Korean waters. Scientific Reports, 9(1).

- Doyle JJ, Doyle JL (1990) A rapid DNA isolation procedure for small quantities of fresh leaf tissue. Phytochem Bull 19:11-15

- Engelen, A. H., Åberg, P., Olsen, J. L., Stam, W. T., Breeman, A. M. (2005). Effects of wave exposure and depth on biomass, density and fertility of the fucoid seaweedSargassum polyceratium(Phaeophyta, Sargassaceae). European Journal of Phycology, 40(2), 149-158.

- González, A., Aguirre, X. (2007). Inter Simple Sequence Repeats (ISSRs). En L. E. Eguiarte, V. Souza \& X. Aguirre (Comp.), Ecología molecular (pp. 567-571). Ciudad de México: Instituto Nacional de Ecología (Semarnat) y Comisión Nacional para el Conocimiento y Uso de la Biodiversidad (Conabio)

- Hahn, T., Lang, S., Ulber, R., Muffler, K. (2012). Novel procedures for the extraction of fucoidan from brown algae. Process Biochemistry, 47(12), 1691-1698.

- Mabeau, S., Kloareg, B., Joseleau, J. P. (1990). Fractionation and analysis of fucans from brown algae. Phytochemistry, 29(8), 2441-2445

- Mendoza Carrión, G. (2003). Estructura genética de Sargassum lapazeanum (Sargassaceae: phaeophyceae) en escalas intrapoblacional, local y regional: Estimación de posibles patrones de dispersión. Tesis de maestría en Ciencias en Uso, Manejo y Preservación de los Recursos Naturales. Centro de Investigaciones Biológicas del Noroeste, S.C. 93 pp.

- Michel, G., Tonon, T., Scornet, D., Cock, J. M., Kloareg, B. (2010). Central and storage carbon metabolism of the brown alga Ectocarpus siliculosus: insights into the origin and evolution of storage carbohydrates in Eukaryotes. New Phytologist, 188(1), 67-81.

- Phillips, N., Smith, C. M., Morden, C. W. (2001). An effective DNA extraction protocol for brown algae. Phycological research, 49(2), 97-102.

- Porebski, S., Bailey, L. G., Baum, B. R. (1997). Modification of a CTAB DNA extraction protocol for plants containing high polysaccharide and polyphenol components. Plant Molecular Biology Reporter, 15(1), 815.

- Zhao, F., Liu, F., Liu, J., Ang, P. O., Duan, D. (2007). Genetic structure analysis of natural Sargassum muticum (Fucales, Phaeophyta) populations using RAPD and ISSR markers. Journal of Applied Phycology, 20(2).

- Zietkiewicz, E., Rafalski, A., Labuda, D. (1994). Genome fingerprinting by simple sequence repeat (SSR)-anchored polymerase chain reaction amplification. Genomics, 20(2), 176-183. 